\title{
Chapter 1 \\ INTERPRETATIONS \\ OR INTERVENTIONS? \\ INDIAN PHILOSOPHY \\ IN THE GLOBAL \\ COSMOPOLIS
}

Christian Coseru

If the history of philosophy could be told without gaps, where and how would Indian philosophy fit in? And, when all is said and done, what are some of the arguments and positions that could be recruited to advance contemporary debates in metaphysics, epistemology, philosophy of mind, logic, philosophy of language, ethics, metaethics, moral psychology, political philosophy, aesthetics, and philosophy of religion? Introductions to Indian philosophy seldom engage these questions. Instead, they proceed to offer prospective readers an appreciation of the richness and real depth of the Indian philosophical tradition in its own terms, and of the intellectual rewards that stand to be gained by delving into it. In this sense, introductions to Indian philosophy differ from introductions to Western philosophy in one significant way: the latter typically lack such incentives, given the widespread assumption (some might say, prejudice) that Western philosophers have shaped not only the way people in the West think about the world today but, in the wake of colonialism, people across the planet. If the study of Indian philosophy, then, is to have scope beyond the confines of intellectual history, questions about its own claims and aspirations to truth cannot be ignored. Indeed, such questions concern the ongoing relevance of its rich repertoire of methods, views, and arguments, and not simply their preservation value.

The chapters of this volume make their own case for how particular figures and texts articulate and seek to answer fundamental questions about the nature of reality and the self, the sources and methods of knowledge, and the norms of moral, social, political, religious, and aesthetic conduct relative to specific goals. They map 
the conceptual terrain of a primarily, but by no means exclusively, Sanskritic philosophical culture of similar ancestry and equal breadth and depth to that of China, Greece, and the Latin West. The present introduction concerns the place that this vast body of literature should occupy in the history of philosophy, and the challenge of championing pre-modern modes of inquiry in an era when philosophy, at least in the anglophone world and its satellites, has in large measure become a highly specialized and technical discipline conceived on the model of the sciences. This challenge is particularly acute when philosophical figures and texts that are historically and culturally distant from us are engaged not only exegetically but also with a view to recruiting their topics and arguments for contemporary philosophical debates.

\section{Canon, style, and the question of method}

One way to address the questions raised here is to consider the current standard philosophy curriculum. When students in Kolkata, Hong Kong, and Tokyo are introduced to philosophy in philosophy programs, for the most part they end up reading some of the same figures and works that students in Oxford, Berlin, and New York do: Plato, Aristotle, Descartes, Kant, John Stuart Mill, and their influential twentieth- and twenty-first-century descendants. But in Kolkata a student might also get exposure to the works of Vātsyāyana, Gangeśa, and Ragunātha Śiromanii, and wonder how their contributions to, say, epistemic norms or category theory fit in with contemporary debates in epistemology and philosophy of language. Likewise, students in Tokyo and Hong Kong might get to read Dōgen and Mozi, and ponder the historical roots of paraconsistent logic and rule consequentialism. On the whole, whether it is read in Oxford or in Kolkata, philosophy's Western bias holds sway, which explains why calls for expanding the canon to accommodate important sources of philosophical skill from other cultures have been largely unsuccessful. Cultural chauvinism and a devaluation of indigenous knowledge sources are partly to blame. But what looms large in the imagination of the great majority of philosophers trained on a predominantly Western curriculum, whether in Kolkata or Oxford, is the issue of incommensurability.

When we see the history of philosophy as a series of dialogues among philosophers pursuing unresolved problems by building on the achievements of their acknowledged forbears we can understand why voices that are not part of the received canon are hard to fit in. Philosophy -the story goes -is constrained by its own genealogy. Consider the student who learns in an epistemology seminar that Gangeśa, a fourteenth-century philosopher from Mithilā and founder of the so-called 'new reason' (Navya-Nyāya) school, is the author of an influential non-semantic theory of truth. By making truth statements dependent on the actual occurrence of cognitive events, Gangeśa is able to block such paradoxical statements as the antinomy of the liar (e.g., Epimenides' paradox) that would be commonplace on, say, a Tarski-inspired, semantic conception of truth. ${ }^{1}$ But to account for Gangeśa's philosophical contribution our student would have to get acquainted with pramana-theory - that is, the theory of the means or sources of knowledge - and with a centuries-old debate about whether truth is apprehended 
intrinsically (svatah) or dependent on extraneous conditions (paratah), and the implications of these positions (and their variants) for self-knowledge, testimony, and the grounds of certainty.

Making sense of Gangeśa's theory of truth by gaining a measure of familiarity with his own Nyāya, Mīmāmsā, and Buddhist interlocutors, then, is a necessary step. But it is by no means sufficient. One must also become acquainted with the distinctive features of the Indian philosophical genre. There are four categories of writing that stand out: (i) terse formulaic assertions (sütra), of an aphorism-like quality, (ii) basic commentary (bhāsya), aimed at unpacking the elusive assertions, (iii) main subcommentary (vārttika), extending the scope of various positions within the commentary usually by way of revision, and further (iv) subcommentarial additions (nibandha), which continue the process of interrogation and revision until all interpretive and argumentative possibilities have been exhausted. Some subcommentaries are limited in scope either to clarifying the syntax of the text and providing more clear alternatives (the vrtti and vivarana) or to elucidating obscure terms (the tịkā).

Furthermore, the commentarial genre comprises a distinct set of nested statements that begins with 'the topic' (visaya) of discussion, followed by the expression 'of a doubt' (samśaya), the citing 'of an opponent's position' (pürvapakșa), an affirmation 'of the decided view' (siddhānta), and ending with a statement 'of purpose' (prayojana). Lastly, there are several types of relations that obtain among the sections of a given commentarial text, all of which aim to ensure some form of dialogical unity. A successive section should either serve as a corollary (prasainga) or as a prerequisite (upodghāta) to a prior section, either exhibit causal dependence (hetutva) on the former or eliminate some potential obstacle (avasara), and either share a common goal (nirvāhakaikya) or act as the causal condition (kāryaikya) of a common outcome. Beyond these structural features there are conceptual rules to ensure that proper channels of belief acquisition are followed, and that beliefs are produced in the right way. And last, but not least, it is paramount that fallacies (hetvābhāsa) of reasoning are carefully identified and avoided.

This cursory acquaintance with the discursive strategies of the commentarial genre may signal analytic rigor or a pedantic scholasticism. Either way, it would seem obvious that engaging Indian philosophy without sharing some of its own presuppositions and concerns about the nature of evidence, the proper place of reason, and the aims of inquiry, is a remote possibility at best. ${ }^{2}$ Most important, the contemporary reader looking for the Indian equivalent of a Descartes, Hume, or Kant (or, closer to the present age, of a Husserl, Sartre, or Quine) would need to suspend belief about style and method and proceed with caution so as not to let assumptions about the 'natural' order of events get in the way. In India, concerns with the justification of true belief occupied thinkers long before it became fashionable in twentieth-century analytic philosophy with Gettier. And debates about consciousness, intentionality, and self-knowledge flourished during the exact same period - the second half of the first millennium when philosophy in the West went into progressive decline after the closing of Plato's Academy in $529 \mathrm{CE}$. 


\section{Shifting attitudes toward doctrine}

The new spirit of rational and scientific inquiry that we associate in the West with Descartes and the British empiricists may be absent in India prior to the advent of British colonial rule in the nineteenth century. ${ }^{3}$ But methodical reasoning of an unprecedented degree of sophistications and technicality, as the Navya Nyāya literature attests, is part of the course. While for the most part still motivated by the need to explain and justify scholastic positions, a new attitude of critical deference to (if not yet distance from) authority, heralds the arrival of a proto-modernity. This new attitude is born of the progressive recognition, first, that beliefs justified without any extra-textual evidence - as traditions of thought indebted to the Mìmāmsā had considered - could be fallible and, second, that causal explanation often trumps appeals to textual coherence and doctrinal consistency.

The roots of this new attitude reach deep into the latter part of first millennium. Indeed, from Dharmottara (eighth century) and Ratnakirti (eleventh century) to Gangeśa (fourteenth century) and Raghunātha (sixteenth century), Indian philosophers engaged in lengthy debates about such epistemic notions as 'defect' (dosa) and 'excellence' (guna). While recognizing the potential fallibility of belief they also noted that veridical cognitions could not be based solely on beliefs one held intrinsically. However, not all traditions of thought embraced this attitude of critical deference. But those that did - primarily the 'new reason' thinkers following in the footsteps of Gangeśa - ended up scrutinizing more carefully the nature and sources of belief formation. Rather than placing the burden of epistemic responsibility on the belief itself (and how it is held), these 'new reason' thinkers gradually shifted the focus to its sources: to how we come to form beliefs in the first place. For instance, they reasoned that if it could be understood that mirrors function the way that they do because of their reflective properties, then the belief that mirrors possess the object reflected, however mysterious these properties might turn out to be, could no longer be justified. If epistemic reliability is a factor of descriptive accuracy, then the view that there are such things as brute common-sense facts becomes untenable.

It is hard to assess how widespread this new attitude toward the scope and aims of philosophical inquiry became in pre-colonial India, and several chapters in this volume seek to tackle this question. What is certain is that a great deal of Indian philosophy, even when directly concerned with the justification of textual, testimonial, or experiential issues, is still permeated by tradition-specific doctrinal assumptions (some of which hinge on the precise number and nature of reliable sources of belief formation (pramāna), while others on whether constructive philosophical debate requires any such doxastic practices at all). Most emblematic of this hermeneutical approach are Mīmāmsaka thinkers such as Kumārila and Prabhākara (seventh to eighth century), whose primary concern is the interpretation of the Vedas and the justification for the observance of Vedic ritual. Kumārila in particular is best known for granting that language has an inexhaustible and unmatched capacity for expression, and for defending a view of the Vedas as repositories of epistemically warranted statements. To 
claim that cognitions formed on the basis of such statements are inherently justified, argues Kumārila, is to say that they are the bearers of language's own self-expressive and self-revealing power.

Doctrinal assumptions are also at the heart of more robustly metaphysical systems of thought concerned with the nature of ultimate reality and the self. When Rāmānuja an influential twelfth-century philosopher of religion and founder of a qualified nondualist school of thought - claims that Advaita (e.g., 'nondual' or lacking in any attributes) conceptions of Brahman are logically incoherent, he appeals to the intuitions of the Sanskrit grammarians about the category of 'being' or 'existence' (sattva). For the grammarians, sattva serves by definition as the locus of generic properties, qualities, and actions. Likewise, when Utpaladeva and Abhinavagupta (tenth to eleventh century) - proponents of a nondualist, but theist, metaphysical system within the Kashmir Śaiva tradition - put forward a quasi-Sartrean conception of the self as the pure and unhindered freedom (svätantrya) of consciousness, they are responding to Buddhist epistemological efforts, championed by Dharmakirti (seventh century) and his followers, to reconcile a conception of consciousness as inherently self-revealing with the cardinal Buddhist doctrines of momentariness and no-self.

\section{Confronting the metaphilosophical question}

As it should be obvious by now, Indian philosophy has its own genealogy and its own rich repertoire of intramural debates. The responsible approach, at least according to the historian of philosophy, would be to chart its course without constant reference to periods and categories in Western philosophy or, worse, outmoded (although still popular) Orientalist conceptions of Indian thought as dominated by religious and spiritual concerns, and, hence, as not really philosophy by the standards of contemporary anglophone philosophy. But the historical approach ignores pragmatic considerations about what, in the absence of cultural affinities, should motivate the study of Indian philosophy outside its traditional sphere of influence, that is, outside the gurukula system and India's modern secular universities. After all, acknowledging the presence of important sources of philosophical insight in the Indian tradition is not enough to motivate contemporary philosophers to engage it, let alone take up the study of Sanskrit.

Whether we are dealing with claims about language, reality, and the self, or with principles of reason and empirical grounding, pragmatic exigencies demand that Indian philosophical views face the same sort of scrutiny as all other presuppositions of the genre. Indeed, from a metaphilosophical standpoint - that is, from the standpoint of inquiry into the nature of philosophy - the question "Is the Indian philosophical genre philosophy?" is a perfectly legitimate way to seek clarity about what should count as philosophy. ${ }^{4}$ But the metaphilosophical question cannot be countenanced, if sufficient care to avoid any one conception of its nature and scope from defining the genre as a whole has not been taken. Philosophy may well be emblematic of the human quest to "understand how things in the broadest possible sense of the term 
hang together in the broadest possible sense of the term." ${ }^{5}$ But that understanding has already been shaped by a long history of such enduring attempts. And yet, answering the metaphilosophical question requires that we bracket historical considerations altogether and eschew their normative challenges. Are the moral and metaphysical lessons of the Upanisads, the Yoga-sütras, and the Bhagavad-Gìtā philosophy, in the critical sense in which that practice has been retrospectively interpreted and adopted in both fourteenth-century India and eighteenth-century Europe? Maybe that is the wrong question. Perhaps we should reconsider, with Ludwig Wittgenstein, Pierre Hadot, and Martha Nussbaum, whether it would not be more appropriate to ask what specific forms of life these texts promote, rather than how philosophical the seemingly insoluble problems they give rise to are. ${ }^{6}$

\section{Indigenism, comparison, and the cosmopolitan ideal}

In so far as philosophy in English or the Anglophone culture at large defines itself against the backdrop of a distinct community of inquiry - nowadays constituted largely of professional philosophers - the question whether the Indian philosophical genre qualifies as philosophy cannot be answered without engaging in the type of intellectual exercise known as 'comparative philosophy'. As Bimal Krishna Matilal observed some time ago, anyone who seeks "to explain and translate systematically from Indian philosophical writings into a European language will, knowingly or unknowingly, be using the method of "comparative philosophy'." Not only explicit attempts to bring Indian and Western philosophers in dialogue, but even text-critical approaches to the genre fall under this category. Doing Indian philosophy in English also means operating with a conceptual vocabulary shaped by the Greek culture of first millennium BCE, the scholasticism of the Latin Middle Ages, and the predominantly French, English, and German intellectual movements of early modern Europe. Thus, one cannot do Indian philosophy without at the same time doing Western philosophy, which means that questions about whether the tenets of one tradition can sustain statement in the other become paramount. Practitioners of the genre 'comparative philosophy' are no strangers to expressing misgivings about comparisons that merely tag theories bearing certain resemblances. And skeptics who champion various forms of indigenism have gone as far as to argue that the adoption of English as a medium for doing Indian philosophy has been profoundly alienating, despite invaluable contributions from such influential early modern Indian philosophers as Krishna Chandra Bhattacharya, Surendranath Dasgupta, Mysore Hiriyana, and Anukul Chandra Mukherji. ${ }^{8}$

Reflecting on this practice as a philosopher trained in both the Indian and the Western, primarily phenomenological, tradition, Jitendranath Mohanty singled out the mutually enhancing value of thinking across cultural boundaries, and the promise that such enterprise might one day usher a new kind of philosophy that is global in scope and outlook. ${ }^{9}$ While we are still a long way from fulfilling that promise, a sort of open-ended and non-committal thinking across traditions has taken root among practitioners of what some now call 'fusion philosophy,' others 'cross-cultural philosophy,' but what might be best described as 'cosmopolitan philosophy.' ${ }^{10}$ This idea is neither 
new nor particularly revolutionary. When Dignāga (c. fifth to sixth century) embarks on his synthesis of the prevalent epistemological, grammatical, and psychological theories of his day and Vācaspati Miśra (tenth century) authors his empathetic and influential commentaries on Advaita Vedānta, Nyāya, and Sāṃkhya-Yoga texts, they do so as members of a Sanskrit cosmopolis. ${ }^{11}$ That cosmopolis endures today among traditionally trained scholars in India and the Indian diaspora. But it functions within, and relative to, an all-encompassing and universalizing cosmopolis that we now call the global West. Doing Indian philosophy today means operating within a larger horizon whose cardinal points of reference are no longer geographical but for the most part conceptual and institutional. Academic philosophy in the global West is a cosmopolitan phenomenon that mirrors the progress of the sciences in its open-ended practice of asking questions and pursuing knowledge. ${ }^{12}$

If one cannot do Indian philosophy in English without doing comparative philosophy, the question naturally arises: is comparative philosophy philosophy? The cosmopolitan approach is partly motivated by a deep skepticism about the possibility of doing philosophy comparatively. If comparative religion is not religion and comparative politics is not politics, how is comparative philosophy philosophy? Answers to this question run the gamut from outright rejection of the possibility of meaningful comparisons, because of the incommensurability of Indian and Western traditions, to the view that the content of these traditions, save for minor stylistic differences, is practically the same. Skeptics point out that while doctrinal and spiritual concerns are not uncommon for Western figures like Augustine, Aquinas, and Kierkegaard, they are not representative of the dominant ideals of discursive rationality and argumentation that Western philosophy has inherited from the Greeks. Brushing aside such superficial dismissals, defenders argue that the most influential Indian philosophers (e.g., Nāgārjuna, Dharmakīrti, Kumārila, Śrīharșa, and Gañgeśa, among others) show as much penchant for rational deliberation and argumentative rigor as Descartes, Hume, Kant, and Wittgenstein.

\section{Philosophical interventions at the confluence of cultures}

So, then: how is comparative philosophy philosophy? Pursuing a similar line of inquiry, Arindam Chakrabarti and Ralph Weber give an example of the sort of interventions in solving long-standing philosophical debates in both India and the West that only comparative philosophy is equipped to handle. ${ }^{13}$ Take reflexivism the thesis that consciousness consists in conscious mental states being implicitly self-aware. In India a group of mainly Buddhist philosophers beginning with Dignāga and Dharmakīrti have defended versions of this thesis against Naiyāyikas, who claimed instead that the self-awareness which accompanies each instance of cognition is inferred from the effects of that cognition. Where the reflexivist thinks that I can know something only to the extent that each instance of cognition is inherently self-revealing or self-illuminating, his opponent counters that such cognitive acts as 'seeing something' are transparent with regard to their own operations. If knowing is an act, we are only aware of it indirectly, when reflection turns 
within and toward its own operations. We see the tree outside the window, not the seeing of that tree. But we can infer that seeing has occurred for someone from the tree that is now seen. And yet, to postulate a basis for self-knowledge outside the structure of experience, or to locate it solely in the conceptual realm, is to problematically assume that experience is an emergent property of something that is not itself experiential.

Readers familiar with contemporary debates in phenomenology and philosophy of mind would immediately recognize these positions as versions of conceptualism versus non-conceptualism with regard to perceptual content, and of the Higher-Order versus First-Order theories of consciousness. Such recognition opens the possibility of intervention, either from the direction of Indian philosophy or, in this particular case, from that of contemporary philosophy of mind, in solving long-standing debates in each tradition. Examples of such interventions abound in the comparative and cross-cultural philosophical literature, often yielding novel ways of tackling long-standing problems. Sometimes they also provide effective platforms from which to interrogate Western hegemonic forms of language, thought, and morality, and take to task those influential philosophers - with Nietzsche as the prototypical example - most responsible for perpetrating a sort of 'neglect by appropriation' approach to Indian philosophy. ${ }^{14}$ On this 'interventionist' model comparative philosophy is philosophy - in the sense of an open-ended concern with asking questions and pursuing knowledge. But is it the sort of philosophy that showcases, if not the unique features, at least the unique trajectory of Indian philosophy?

One worry is that such interventions end up treating Indian philosophy as a sort of standing reserve to be mined for interesting or even original statements, with utter disregard for their historical context and significance. We only need look at such "manuals of reason" as Mokṣākaragupta's Tarkabhāsāa (twelfth century) and Annambhatța's Tarkasamgraha (seventeenth century) to realize that these worries are misplaced. What is distinctive about these indigenous interventions is precisely their systematic effort to identify, analyze, and evaluate the basic tenets of each school, often disregarding context or attribution, with the aid of various epistemological, methodological, and logical techniques.

An altogether different sort of worry is that many such interventions are anachronistic. Take the example of cutting across historical and cultural boundaries to make the case that, say, the twelfth-century Advaitin Śriharṣa rather than Gettier should be credited with the Gettier Problem. But a history of philosophy without gaps will have to look beyond linear narratives and realize that such juxtapositions are inevitable if we are to do justice to the progression of thought. If Śriharșa is the first to frame and illustrate the (Gettier) problem, and the first to venture interesting solutions, then he addresses not only the concerns of his twelve-century Naiyāyika opponents, but also those of late twentieth-century analytic epistemology.

I have already hinted that chronologies are relative to a given philosophical culture and epoch. If 'classical' is an apt term for much of the early period of Indian philosophy, 'mediaeval' is not. There is no break with the past in India similar to the onset of the European Middle Ages. Foundational sūtras for the Sāṃkya, Yoga, 
Buddhist, Jaina, Cārvāka, Nyāya, Vaiśeșika, Mīmāṃsā, and Vedanta traditions are continuously composed over several centuries beginning around $500 \mathrm{BCE}$, and the commentarial tradition continues well into the middle of the second millennium of the Common Era. ${ }^{15}$

Apart from these worries there is also the objection that this sort of cosmopolitan intervention either ignores or glosses over issues of cultural difference and conceptual incommensurability. Indian philosophy is host to conceptual, argumentative, and experiential strategies that do not map neatly onto Western categories and practices. Render classical Indian logic in Western terms, and the anumāna system of inference ends up being indistinguishable from the Aristotelian syllogism. Retain the original format with its distinctive steps and characteristics, and the Indian tradition of debate can seem alien and contrived. One response to this objection is predictably straightforward: whether one thinks inside or outside the categorical framework of a particular philosophical tradition or culture, ${ }^{16}$ one need not endorse its conceptual schema. Mādhyamika philosophers make good use of the sophisticated categorical frameworks of Abhidharma, Nyāya, and the Sanskrit grammarians, and yet treat them as 'worldly conventions' (lokasamvriti) that do not capture the way things are ultimately. For Mādhyamikas, just as for many contemporary global antirealists, seeking to capture the intrinsic order of reality through a categorical framework (be it that of Vaiśeșika or Aristotle) has to contend with the very notion of an 'essence' or 'intrinsic order' of things. Effective as they may be, such categories are subject to revision. And, if it should turn out that there are better ways of knowing and being, it is hard to see how pursuing them would not be preferable to the status quo.

Sometimes the best way to make progress is not to start anew, by breaking with the past, but to consider an alternative course, specifically one that philosophy might have taken had it been shaped by a different cultural geography. In the West philosophy begins in wonder about the natural world and the reach of reason; in India, by contrast, it begins in speculations about the origins, nature, and function of language as a vehicle of philosophical insight. While the Pre-Socratics wonder about the ultimate principle of things (arche) using the vocabulary of nature, Indian philosophers beginning with Jaimini (fourth century BCE), Gautama (second century CE), and Nāgārjuna ( $f$ l. second century CE) are concerned with finding out what the relation between words and their referents is ultimately like. Is it a primordial (autpattika) relation, as Jaimini claims? Does it depend on a certain capacity to generate knowledge that awareness-episodes ( $\operatorname{pram} \bar{a}$ ) have, as Gautama stipulates? Or is this relation simply the result of an illegitimate metaphysical use of language prone to reification, as Nāgārjuna would have it? As should be obvious to all readers of Cratylus, such concerns are by no means unique to the Indian philosophical tradition. But in India they contribute to the articulation of a sophisticated philosophy of language that does not become the norm in the West until the middle of the eighteenth century.

If the study of Indian philosophy is to resist retreat into the familiar terrain of tradition and its scholastic proclivities, perhaps a confluence of perspectives rather than their comparison is more methodologically apt. Such confluence is not without historical precedent. Contact between India and the Greek world following Alexander the 
Great's military campaigns set the stage for a work of Buddhist apologetics (the Milinda Pañha), and allowed such attitudes as 'freedom from emotion' (apatheia) and 'contentedness' (eukolia) - which Pyrrho is said to have witnessed among the so-called 'naked wise men' (gymnosophists) of India - to inform Hellenistic skepticism. The cosmopolitan oasis towns of Bukhara, Samarkand, Kashgar, Khotan, and Kucha served as a land bridge between Indian Buddhists and Chinese intellectuals drawn to the philosophy of emptiness. Their encounter resulted in a practice of matching Buddhist and Daoist concepts ( $k_{o}-i f_{0}$-chiao) that, by the fourth century $\mathrm{CE}$, would render core Mahāyāna Buddhist ideas indistinguishable from the teachings of Daodejing and Zhuangzi. And, the more tolerant sixteenth- and seventeenth-century Mughal rules of Akbar and Shah Jahan made possible Dārā Shukoh's momentous translation project of the Upanișads, exposing Persian and Arabic intelligentsia to the same Sanskrit philosophical lore that a century and a half later would end up, via translations from Persian to Latin, on Schopenhauer's desk.

Significant as these confluences are we must not forget that they tell as much of a story of admiration as of appropriation, assimilation, and refutation. For the anonymous compilers of Milinda Pañha ('Questions of Milinda'), the Greek philosopher-king Milinda (Menander I) is simply a foil for Nāgasena's compelling defense of the Buddhist no-self view. Pyrrho, to the extent that we can reconstruct his views, mainly engages with Democritus, Plato, and the Eleatics. And Schopenhauer's main interlocutor is Kant rather than Yājñavalkya, despite his high regard for the Upanișads.

As we look to the future of philosophy in the twenty-first century we can only hope that a better knowledge of Indian philosophy would result in many and more fruitful conversations about knowledge, being, and what there is, and about the proper place of reason in the midst of it all.

\section{Notes}

1 See Mohanty (1966), Matilal (1985), and Phillips (2012: 87-91) for detailed treatments of Ganggeśa's theories of truth that also engage contemporary issues in epistemology.

2 As I have argued elsewhere (Coseru 2012: 279), the most important aspect of this intercultural philosophical engagement is not the recognition that there are different approaches to philosophy, but the promise that such recognition holds for enhancing, refining, and expanding the range of argument and possibilities that are available to us.

3 Ganeri (2012:6) argues otherwise, but see Garfield (2014) and Phillips (2016) for more skeptical views about whether the outlook of 'new reason' Naiyāyika like Raghunātha is of a piece with that of early modern thinkers in Europe.

4 Perrett (2016:3), rightly in my view, notes that as exasperating as this question can be for Indologists and historians of Indian philosophy, is it perfectly legitimate if we are to distinguish between 'descriptive' and 'evaluative' (or 'normative') uses of the term 'philosophy'. By the same token one could ask the question: "Is this creative form art?" or "Is this writing literature?" and conclude that while something does descriptively fall under the category 'art' or 'literature,' it may still not belong to the class of good art or literature.

5 Sellars (1962: 1).

6 See Wittgenstein (2001: 192), Hadot (2001: ch. 1), and Nussbaum (1994: 14). 


\section{INTERPRETATIONS AND INTERVENTIONS}

7 Matilal (1971: 13).

8 Daya Krishna went so far as to claim that "anyone who is writing in English is not an Indian philosopher" and thus is doing neither philosophy nor Indian philosophy (in Bhushan and Garfield 2011: xiii-xiv).

9 Mohanty (1992: 401).

10 Siderits (2015) canvases the 'fusion philosophy' model, while Garfield (2002) and Ganeri (2012) champion the 'cross-cultural' and 'cosmopolitan' approaches, respectively.

11 Pollock (2006: 12) argues that in exercising its transregional cultural power, Sanskrit did engender a conceptual and methodological universalism. But the Sanskrit cosmopolis "never objectified, let alone, enforced its universalism" (Pollock 2006: 12).

12 Halbfass (1988: 273) thinks that this is precisely the reason why Western philosophy has undergone such dramatic changes in modern history.

13 Chakrabarti and Weber (2016: 15ff.).

14 Bilimoria (2008: 375) finds in Nietzsche's ambivalent encounter with Asian perspectives the resources of an 'instrumentalist' approach to Asian thought, one whose lingering effects comparative philosophy has been struggling to counter for nearly a century.

15 New attempts at the periodization of Indian philosophy that reflect its own evolution rather than how that evolution maps onto periods and movements in Western philosophy are found in Franco (2013) and contributions therein.

16 See Frazier (2014: 7) for a plea for thinking with, rather than against, Indian categories inherited from the Naiyāyikas and their followers, and thus "inside the box" rather than outside of it.

\section{Bibliography}

Bhushan, Nalini and Garfield, Jay L. 2011. Eds. Indian Philosophy in English: From Renaissance to Independence. New York: Oxford University Press.

Bilimoria, Purushottama. 2008. "Nietzsche as 'Europe's Buddha' and 'Asia's Superman'." Sophia 47: 359-376.

Chakrabarti, Arindam and Ralph Weber. 2016. "Introduction.” In Comparative Philosophy without Borders, ed. Arindam Chakrabarti and Ralph Weber, 2-33. London: Bloomsbury.

Coseru, Christian. 2012. Perceiving Reality: Consciousness, Intentionality, and Cognition in Buddhist Philosophy. New York: Oxford University Press.

Franco, Eli. 2013. Ed. Periodization and Historiography of Indian Philosophy. Vienna: De Nobili Research Library.

Frazier, Jessica. 2014. "Introduction." In Categorization in Indian Philosophy: Thinking Inside the Box, ed. J. Frazier. London: Routledge.

Ganeri, Jonardon. 2012. The Lost Age of Reason: Philosophy in Early Modern India:1450-1700. Oxford: Oxford University Press.

Garfield, Jay L. 2002. Empty Words: Buddhist Philosophy and Cross-Cultural Interpretation. New York: Oxford University Press.

Garfield, Jay L. 2014. "Review of Jonardon Ganeri, The Lost Age of Reason: Philosophy in Early Modern India 1450-1700.” Philosophical Quarterly 64(255): 343-346.

Hadot, Pierre. 2001. Exercices spirituels et philosophie antique. 2nd ed. Paris: Albin Michel.

Halbfass, Wilhelm. 1988. India and Europe: An Essay in Philosophical Understanding. Albany: State University of New York Press.

Matilal, Bimal K. 1971. Epistemology, Logic and Grammar in Indian Philosophical Analysis. The Hague: Mouton.

Matilal, Bimal K. 1985. Logic, Language, and Reality: Indian Philosophy and Contemporary Issues. 2nd ed. Delhi: Motilal Banarsidass, 1990.

Mohanty, J. N. 1966. Gangeśs's Theory of Truth, Containing the Text of Gaingeśa' Prämānya(jñapti)vāda. 2nd rev. ed. Delhi: Motilal Banarsidass, 1989.

Mohanty, J. N. 1992. “On Matilal's Understanding of Indian Philosophy." Philosophy East and West 42(2): 397-406. 
Mohanty, J. N. 1997. "Introduction: Bimal Matilal, the Man and the Philosopher." In Relativism, Suffering, and Beyond: Essays in Memory of Bimal K. Matilal, ed. P. Bilimoria and J. N. Mohanty, 1-15. New Delhi: Oxford University Press.

Nussbaum, Martha. 1994. The Therapy of Desire: Theory and Practice in Hellenistic Ethics. Princeton: Princeton University Press.

Perrett, Roy. 2016. An Introduction to Indian Philosophy. Cambridge: Cambridge University Press.

Phillips, Stephen. 2012. Epistemology in Classical India: The Knowledge Sources of the Nyāya School. London: Routledge.

Phillips, Stephen. 2016. "Creative Commentary." Philosophy East and West 66(3): 1020-1026.

Pollock, Sheldon. 2006. The Language of Gods in the World of Men: Sanskrit, Culture, and Power in Premodern India. Berkeley: University of California Press.

Sellars, Wilfred. 1962. "Philosophy and the Scientific Image of Man." In Frontiers of Science and Philosophy, ed. Robert Colodny, 35-78. Pittsburgh, PA: University of Pittsburgh Press.

Siderits, Mark. 2015. Personal Identity and Buddhist Philosophy. 2nd ed. Farnham: Ashgate.

Wittgenstein, Ludwig. 2001. Philosophical Investigation. 3rd ed. Trans. G. E. M. Anscombe. Oxford: Blackwell. 